\title{
THE VEGETABLE AND GLASSHOUSE RESEARCH STATION, IRELAND
}

\section{By DR. DIARMUID MURPHY}

$\mathrm{O}^{\mathrm{s}}$ N September 20, Mr. Sean Lemass, Taoiseach (Prime Minister) of Ireland, opened the Vegetable and Glasshouse Research Station of An Foras Taluntais (Agricultural Institute), Kinsealy, Malahide, Co. Dublin. Mr. John G. Litton, chairman of the Couneil of An Foras Taluntais and Dr. T. Walsh, director, welcomed An Taoiseach to the Station. The opening was attended by members of the Council of An Foras Taluntais, senior staff members and 150 guests.

Kinsealy is in the centre of the vegetable growing area of North County Dublin, and An Foras Taluntais acquired 150 acres in the area in 1959. The farm is $70 \mathrm{ft}$. above sea-level and is about 8 miles from Dublin. The solid geology consists of pale grey, coral reef limestone, overlain by gravelly boulder drift of predominantly limestone composition deposited by ice during the Weichsel glaciation. 90 per cent of the soil on the farm is a well-drained loam to clay loam texture of high base status. Available phosphorus-levels are moderate, but available potassiumlevels are low (due to fixation by large amounts of illite).

The station serves as the headquarters for the Horticulture and Forestry Division. In addition, the following Departments of other divisions of An Foras Taluntais have research facilities at the station: Soil Physics (Soils Division); Cereal Chemistry and Nematology (Plant Sciences and Crop Husbandry Division). Staff of the National Soil Survey and of the Plant Nutrition Department (Soils Division) use Kinsealy as a centre of operations, and the Grassland Management and Animal Physiology Departments (Animal Production Division) also conduct experimental work at the Station. The following buildings are now complete: the main laboratory and administrative block, the glasshouse and propagating unit, the boiler unit, and the nematology unit. It is proposed to build a mushroom research house.

The main laboratory and administrative block contains a library and assembly hall (570 sq. ft.), canteen to seat 50 , administrative offices $(2,200 \mathrm{sq}$. ft.), and laboratories for cereal chemistry $(2,040$ sq. ft.), soil physics (2,380 sq. ft.), horticultural chemis- try and biochemistry (2,720 sq. ft.), plant pathology $(1,100 \mathrm{sq}$. ft.) and mushroom research (850 sq. ft.). In addition, there is a workshop, storage space, dark room and provision for growth rooms.

The main laboratory building runs north-south with the main entrance in the middle. The library and conference hall are over the main entrance, making for ease of access for lectures or conferences. A corridor runs the length of the building with laboratories and offices opening off. The building was originally planned as a single story structure but due to the topography of the site it was found more desirable to build a semi-basement under the North Block, thereby increasing the available floor space by almost 50 per cent. The entire building, which is $310 \mathrm{ft}$. long by $42 \mathrm{ft}$. wide, is planned on the modular principle, $10 \mathrm{ft}$. being the standard module width. The depth of the laboratories is $17 \mathrm{ft} .6 \mathrm{in}$. Adequate office space separate from the laboratories has been provided for graduate staff.

The glasshouse unit consists of 13 houses, each $100 \times 30 \mathrm{ft}$., and two propagating houses, $75 \times 20$ $\mathrm{ft}$. One of the glasshouses is designed as a lysimeter house, allowing exact nutritional and moisture studies on a wide variety of plants. It is proposed to build more glasshouses in order to extend the research programme.

A boiler-house serves the entire heating needs of the glasshouses and laboratory buildings. The main boiler uses compressed peat briquettes and is the first completely automatic peat-burning boiler in Ireland.

Because of the nature of the work involved, the nematology laboratory $(2,560$ sq. ft.) has been placed at a distance from other buildings. It is planned for a smooth flow of work and contains the following rooms: soil reception, drying, extraction and microscope rooms, plus offices, research laboratory and dark room.

The greater part of the research effort at Kinsealy is on horticultural crops, under two headings: vegetable crops and glasshouse crops. A great deal of information is still lacking on the needs of vegetable crops as regards climate, soil suitability, varieties, husbandry methods and nutritional requirements

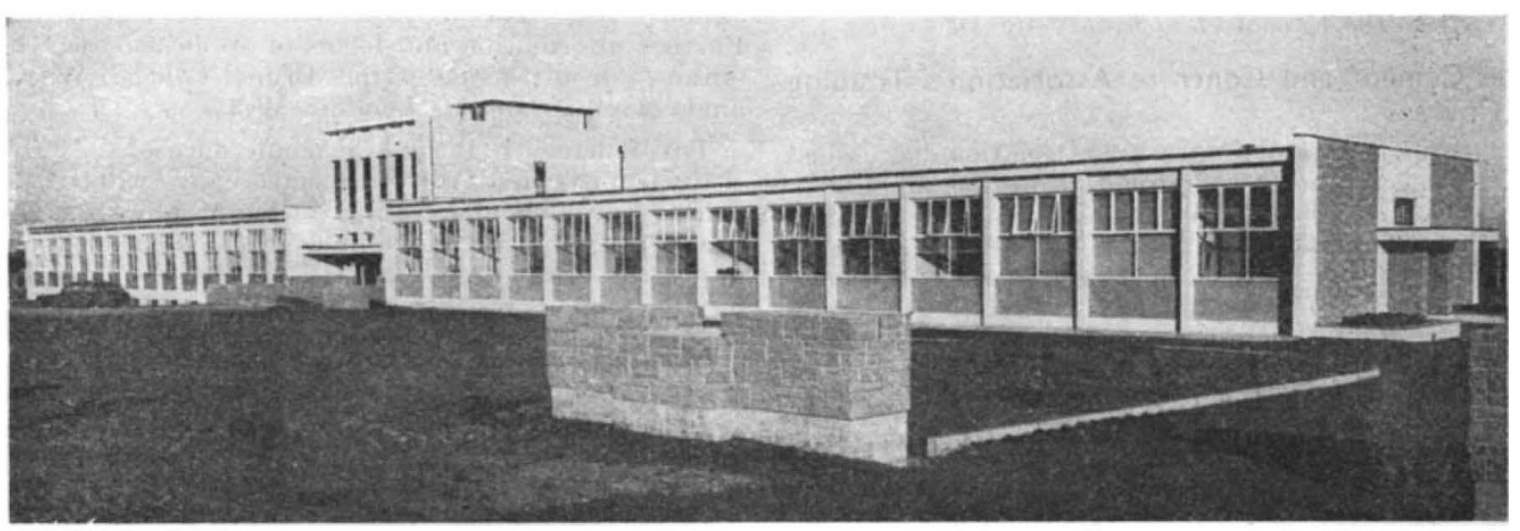

Fig. 1. New research laboratory and administrative building at Kinsealy, Co. Dublin 
under Irish conditions. All tho common vegetable crops are being grown in a series of field trials. Aspects also being investigated are variety breeding (with emphasis on new varieties suitable for packaging and processing), and weed control.

The glasshouse vegetable work is at present concentrated on tomatoes, cucumbers and lettuces. Already valuable information has been obtained on methods of extending the tomato season. Flower crops under glass are also being examined so that information may be gained which will enable growers to cater for the home and export market.

The Chemistry and Biochemistry Department serves the needs of the vegetable and glasshouse crops sections and a comprehensive research programme is being developed, including work on manurial and trace element problems. It is proposed to build up a large laboratory programme dealing with the chemical and biochemical factors of 'quality' in fruit and vegetables. In addition, work is being done on the chemical aspects of Irish honey-a product capable of great development.

The mushroom research unit is concentrating on the cytological and genetical aspects. A close liaison is maintained with growers and many problems of a practical nature have received attention. To supplement the research facilities at Kinsealy a production unit is available at another centre of An Foras Taluntais. It is proposed to erect a commercial-scale mushroom house at Kinsealy.

A feature of the research work which is of special practical value is that, due to the nearness of the Dublin market, test marketing projects can be carried out on vegetables and flowers in conjunction with the Rural Economy Division of An Foras Taluntais.

The work of the Soil Physics Department deals with research in soil texture and structure, and drainage. The Department also uses Kinsealy as a centre from which soil studies are conducted at a number of other stations. Facilities provided include equipment for soil mechanics and physics, and soil moisture studies. Particular attention is being paid to the water requirements of a number of vegetable crops. In addition, the lysimeter house provides facilities for accurate water balance studies.

The Cereal Chemistry Department has a comprehensive research programme on both the applied and fundamental aspects of wheat and other cereals. Equipment includes drying facilities for 50 samples simultaneously, Brabender grain cleaner, Buhler semi-automatic mill, dough-testers (Brabender farinograph and extensograph) and complete experimental bakery. Factors such as yield, early maturity, resistance to sprouting (of fundamental importance in Ireland because of high rainfall), milling and baking quality, and protein content of wheat are under investigation. Studies on malting and feoding barley are proceeding, and studies on oats are projected.

The Nematology Department undertakes such work as the study of bionomics, host-range and economic importance of eelworms and population studies of eelworms. An important aspect of the work is certification and quarantine of seeds and plants. Other work undertaken includes search for resistant plant varieties, and testing the mode of action and efficiency of nematicides under Irish conditions.

While the research station at Kinsealy is comparatively young, it presents a unique opportunity for co-operation between research workers of many disciplines. As a result of the research programme in hand, much information has already been gained and has been made available to the horticultural and agricultural industry in Ireland.

\section{NUCLEAR CHEMISTRY}

A $\mathrm{N}$ informal discussion on nuclear chemistry, organized by the Atomic Energy Research Establishment, Harwell, was held in the Inorganic Chemistry Department at the University of Oxford during September 18-21. The meeting followed similar discussions previously held, at the University of Durham in 1960, and at CERN, Geneva, in 1961. On this occasion the subject was "Fission and other Low Energy Nuclear Processes". Sixty-one papers were presented covering fission, spallation, radioactive decay; the energy released in these processes; and the general techniques for observing them. Abstracts of the papers have been published as a Harwell memorandum number $A E R E-M$ 1078, but in view of the informal nature of the meeting no other record has been made. About 180 delegates attended, representing fifty different laboratories in Europe and the United States.

In the opening paper W. J. Swiatecki (University of California) described recent developments in the liquid drop model of the nucleus, and these were applied by T. Sikkeland (Berkoley) to his work on fission induced by heavy ions. Here the compound nuclei formed by the interaction of heavy ions carbon-12 and oxygen-16 on targets from praseodymium-141 to plutonium-240 cover a wide range of charge to mass ratios. The kinetic energy released was shown to agree closely with detailed predictions of the liquid drop model. In the course of the discussion it was pointed out that the fission energy, which arises from the coulomb repulsion of initially contiguous nuclei, is extremely sensitive to the shape of the nuclei, and provides a valuable means for studying nuclear deformation.

S. G. Thompson (Berkeley), R. H. Tomlinson (MeMaster University, Canada), and R. Vandenbosch (Copenhagen) all reported experimental support to the theoretical picture that at fission one fragment tends to assume a closed shell configuration, whereas the other fragment is more deformable, takes up excitation, and emits neutrons.

Discussion on fission yields concentrated mainly on the relative amounts of isomers of different spin. Radiochemical measurements of the yields of the isomers reported by I. F. Croall (Atomic Energy Research Establishment) implied that the initial fragments were of high angular momentum, and this conformed with the measurements of the directional correlation between prompt $\gamma$-rays and primary fission fragments reported by M. M. Hoffmann (Los Alamos).

Perhaps the most important contributions to the meeting were those on semi-empirical mass formulæ based on the new tables for nuclear masses recently published by Everling, Koenig, Mattauch, and Wapstra. H. Kummel (Max-Planck Institute, Mainz) accounted for the systematic trends in the masses of all known nuclei to an accuracy of $1 \mathrm{MeV}$ by the use of fifty parameters. W. J. Swiatecki showed that 